\title{
PERAN KOPERASI DALAM KEPUTUSAN KEUANGAN KELUARGA PADA MASA PANDEMI COVID-19
}

\section{Diyan Lestari ${ }^{*}$, Vina Meliana ${ }^{2}$}

12 Manajemen, Fakultas Bisnis dan Komunikasi, Institut Teknologi dan Bisnis Kalbis

Jl. Pulomas Selatan Kav. 22, Kayu Putih, Jakarta Timur

*Email korespondensi: diyan.lestari@kalbis.ac.id

\begin{abstract}
Household financial decision is an important component to improve household welfare which impact on economy stability. While cooperatives as cornerstone play important role to improve their member prosperity. This study aims to analyze the role of Cooperatives on household decision making during the Covid-19 pandemic which examines the effect of financial literacy, lifestyle, and perceived risk on household financial decision during the Covid-19 pandemic with training by Cooperative as the moderating variable. This study uses 185 sample by using purposive sampling technique and implement the moderated regression analysis (MRA) to analyze the data. The result shows, financial literacy and perceived risk affect household financial decision during the Covid-19 pandemic, while lifestyle do not affect the household decision making. Training by Cooperative moderates all the effect of independent variables on dependent variable.
\end{abstract}

Keywords: Cooperative, Financial Decision, Financial Literacy, Perceived Risk

\section{Corresponding Author:}

Diyan Lestari

Manajemen, Fakultas Bisnis dan Komunikasi, Institut Teknologi dan Bisnis Kalbis

Jl. Pulomas Selatan Kav. 22, Kayu Putih, Jakarta Timur

*Email: diyan.lestari@kalbis.ac.id

Received: 26 Juli 2021

Accepted: 08 Oktober 2021

Online: 31 Des 2021

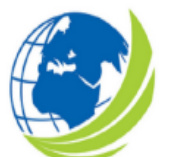

Jurnal

(C) The Author(s) 2021

DOI: $10.36407 /$ jmsab.v4i2.437

Manajemen

Strategi dan

Aplikasi

Bisnis,

Vol 4, No. 2, 2021,

CC BY: This license allows reusers to distribute, remix, adapt, and build upon the material in any medium or format, so long as attribution is given to the creator. The license allows for commercial use. 


\section{PENDAHULUAN}

Pandemi Covid-19 memberikan dampak yang besar pada berbagai sektor ekonomi di Indonesia. Berdasarkan data Badan Pusat Statistik (BPS), GDP Indonesia mengalami pertumbuhan negative pada tahun 2020 sebesar $-2.19 \%$ sebagai dampak dari pandemi Covid19 (tempo.co, 2021). Hal tersebut juga ditunjukkan dengan adanya penurunan kinerja oleh banyak perusahaan di berbagai sektor, khususnya Usaha Mikro Kecil dan Menengah (UMKM) yang terdampak cukup besar dengan adanya pandemi Covid-19 (Muhyiddin \& Nugroho, 2021). Pada dasarnya, kondisi ekonomi yang baik di sebuah negara tentunya ditunjang oleh solidnya kondisi ekonomi rumah tangga di negara tersebut. Berdasarkan data, pengeluaran rumah tangga memberikan kontribusi yang cukup besar bagi pertumbuhan ekonomi di Indonesia yaitu sebesar $56.93 \%$ pada Q1 tahun 2021, yang jika dibandinkan tingkat pengeluaran rumah tangga di Indonesia pada tahun 2020 sedikit lebih tinggi yaitu sebesar $57.66 \%$ (Dewi, 2021). Oleh karena itu, sangatlah penting untuk mengoptimalkan peran rumah tangga dan mempercepat pemulihan ekonomi rumah tangga melalui pengelolaan keuangan yang baik dengan pembuatan keputusan keuangan yang bijak. Secara umum, setiap keputusan keuangan rumah tangga juga akan mencerminkan perilaku keuangan rumah tangga. Semakin baik rumah tangga melakukan pengelolaan keuangan, termasuk di dalamnya pengelolaan pengeluaran, maka diharapkan akan memberikan dampak yang baik bagi kondisi keuangannya, khususnya untuk menghadapi berbagai kondisi ketidakpastian. Pandemi Covid19 dan berbagai krisis yang ada, pada dasarnya memberikan pembelajaran bagi individu untuk lebih bersiap dalam menghadapi ketidakpastian. Oleh karena itu, sangatlah penting untuk memiliki kesiapan dalam menghadapi ketidakpastian.

Lembaga keuangan, termasuk di dalamnya bank dan lembaga keuangan non-bank memiliki peranan penting bagi perekonomian. Sebuah negara dengan perkembangan institusi keuangan yang pesat cenderung memiliki pertumbuhan ekonomi yang pesat. Pada dasarnya, Lembaga keuangan memiliki fungsi utama sebagai Lembaga intermediary. Lembaga tersebut memberikan berbagai layanan kepada masyarakat, khususnya layanan dalam bentuk saving dan pemberikan kredit. Akan tetapi, selain peranan tersebut Lembaga keuangan juga diharapkan dapat memberikan kontribusi lebih kepada masyarakat, misalnya dengan memberikan pelatihan kepada masyarakat. Lembaga keuangan, salah satunya adalah Koperasi tidak hanya terbatas memberikan layanan sebagai Lembaga perantara, akan tetapi juga diharapkan dapat membantu masyarakat dalam upaya meningkatkan kesejahteraannya. Koperasi, dikenal sebagai soko guru pada ekonomi Indonesia dan merupakan Lembaga atau institusi yang terdiri dari berbagai individu dan institusi yang berdasarkan pada prinsipprinsip Koperasi dengan tujuan untuk mensejahterakan anggotanya (Halid, 2014). Koperasi, memiliki peranan penting dan memiliki nilai unik dalam mensejahterakan anggotanya dan memiliki peranan penting dalam meningkatkan perekonomian (Bello, 2005). Parnell (2001) menyatakan bahwa Koperasi memiliki nilai, norma, dan prinsip-prinsip unik yang memungkinkan para anggotanya berpartisipasi dalam meningkatkan kesejahteraan. Oleh karena itu, sangatlah penting untuk mengoptimalkan peranan Koperasi dalam rangka meningkatkan pertumbuhan ekonomi dan kesejahteraan masyarakat.

Penelitian ini bertujuan untuk menganalia peranan Koperasi dalam keputusan keuangan Keluarga pada masa pandemic Covid-19 yang juga membahas berbagai aspek penting yang mempengaruhi keputusan keuangan, yaitu literasi keuangan, gaya hidup, dan persepsi risiko. Keputusan keuangan keluarga, memiliki peranan penting dalam ekonomi sebuah negara. Keputusan keuangan yang bijak dari rumah tangga diharapkan akan memberikan dampak positif terhadap pertumbuhan ekonomi. Pembuatan keputusan, khususnya terkait dengan konteks keuangan membutuhkan wisdom, keahlian, pengetahuan, dan berbagai faktor lainnya. Mengidentifikasi berbagai aspek dalam keputusan keuangan akan memberikan insight baru untuk menggali perspektif individu dalam pembuatan keputusan keuangan. Secara umum, keputusan keuangan rumah tangga sangatlah bervariasi dan berbeda antara individu satu dengan individu yang lain, baik dalam keputusan pembelian, tingkat utang, pembayaran tagihan, menabung, investasi, dan lain sebagainya (Kim, Gutter, \& Spangl, 2017). Penelitian sebelumnya menyatakan bahwa literasi keuangan, gaya hidup, dan persepsi risiko merupakan faktor penting yang mempengaruhi keputusan keuangan. Selain itu, peranan institusi keuangan, termasuk pelatihan yang diberikan Koperasi merupakan aspek penting yang dapat memoderasi pengaruh faktor tersebut dalam keputusan keuangan. 
Literasi keuangan, dapat didefinisikan sebagai proses untuk memperoleh pengetahuan keuangan, memahami kerangka kerja dari instrument-instrumen keuangan, dan mengimplementasikan pengetahuan keuangan tersebut dalam berbagai keputusan keuangan. Berdasarkan survei yang dilakukan oleh Otoritas Jasa Keuangan (OJK) pada tahun 2019, indeks literasi keuangan Indonesia masih relative rendah, yaitu sekitar 38.03\%, sedangkan indek inklusi keuangan jauh lebih tinggi yaitu sebesar 76.19\%. Angka tersebut lebih tinggi dibandingkan dengan data di tahun 2016, di mana indeks literasi keuangan hanya sebesar 29.7\% dan indeks inklusi keuangan sebesar 67.8\% (OJK, 2020). Tingkat literasi keuangan yang rendah dapat mengakibatkan keputusan keuangan yang buruk, termasuk di dalamnya pemilihan instrument keuangan yang kurang tepat. Prasad \& Nataraj (2017) menyatakan bahwa literasi keuangan berpengaruh terhadap keputusan keuangan. Mereka menyimpulkan bahwa literasi keuangan pada dasarnya merupakan sebuah usaha akan tetapi pada akhirnya akan memberikan manfaat kepada individu karena berbagai produk dan layanan keuangan yang cukup kompleks dan dapat menimbulkan kebingungan bagi individu dalam melakukan pemilihan produk maupun layanan. Tingkat literasi keuangan yang tinggi akan memberikan manfaat kepada individu dalam pengambilan keputusan. Keputusan keuangan merupakan keahlian penting bagi individu untuk mampu menghadapi perubahan yang dinamis. Lusardi (2013) menyatakan bahwa literasi keuangan memberikan pengaruh positif terhadap keputusan keuangan. Fong, Koh, Mitchel, \& Rohwedder (2021) juga menyatakan bahwa tingkat literasi keuangan yang lebih tinggi berdampak pada keputusan keuangan yang lebih bijak.

Gaya hidup juga merupakan faktor penting dalam keputusan keuangan. Gaya hidup dapat digambarkan sebagai cara hidup individu yang dicerminkan dari aktivitas, interest, dan opininya. Gaya hiudp, merupakan istilah dari psikologi dan sosiologi yang mengacu pada cara hidup (Bei, 2000). Gaya hidup juga dapat didefinisikan sebagai cara individu dalam berinteraksi dengan lingkungannya yang juga mencerminkan pola hidup, termasuk mengenai bagaimana mereka mengatur pengeluaran dan melakukan pembelian. Setiap individu tentunya memiliki gaya hidup yang unik dibandingkan dengan individu lain. Lin \& Shih (2012) menemukan bahwa gaya hidup berpengaruh terhadap keputusan keuangan. Secara umum, gaya hidup dan karakteristik kepribadian merupakan hal penting dalam membentuk karakter individu. Sahoo, Behera, \& Sahoo (2017) menyatakan bahwa karakteristik gaya hidup meliputi kemampuan personal, kepercayaan diri, tingkat kemandirian, dan juga gaya hidup. Nagpal \& Bodla (2009) menemukan bahwa gaya hidup berpengaruh terhadap keputusan keuangan.

Aspek penting lainnya yang berpengaruh terhadap keputusan keuangan adalah persepsi risiko. Hal tersebut terkait dengan preferensi, pengalaman, dan cara pandang individu terhadap suatu ketidakpastian. Hal tersebut dapat merupakan hal yang rasional maupun irasional yang berperan penting dalam ketidakpastian (Sindhu \& Kumar, 2014). Persepsi risiko juga mencerminkan bagaimana komunikasi investor dalam mengambil risiko yang terkait dengan faktor psikologi. Tingkat preferensi risiko investor akan membantu mereka mengukur tingkat risiko. Menurut Sitkin \& Weingart (1995), individu dengan tingkat perepsi risiko yang lebih besar cenderung mengambil projek yang lebih berisiko dan cenderung mempersepsikan ketidakpastian menjadi sesuatu yang biasa. Secara umum, individu dengan tingkat persepsi risiko lebih rendah akan lebih menyukai berinvestasi pada produk yang aman. Ainia \& Lutfi (2019) menemukan bahwa persepsi risiko berpengaruh terhadap keputusan keuangan individu. Bairagi \& Chakraborty (2018) meneliti mengenai keputusan keuangan investor retail di mana mereka cenderung konservatif. Hasil penelitian menunjukkan bahwa persepsi risiko berpengaruh terhadap keputusan keuangan, termasuk di dalamnya terkait dengan pemilihan portofolio investasi. Bairagi \& Chakraborty (2018) menjelaskan bahwa persepsi merupakan judgement dari proses kognitif yang dapat dikarakteristikkan melalui tingkat keahlian dan pengalaman. Mereka mendefinisikan persepsi risiko sebagai pandangan individu atau investor yang terkait dengan risiko yang didasarkan pada pengetahuan, keahlian, dan pengalaman.

Tujuan utama dari Koperasi adalah untuk meningkatkan kesejahteraan para anggotanya dengan menerapkan nilai, norma, dan mekanisme tertentu. Koperasi memiliki salah satu prinsip pendidikan, pelatihan, dan informasi yang berarti bahwa Koperasi menyediakan platform edukasi bagi para anggotanya dan juga memberikan ruang bagi para anggotanya untuk memberikan kontribusi bagi pengembangan Koperasi dan anggotanya. 
Salah satu Koperasi yang rutin menyelenggarakan kegiatan pendidikan, pelatihan, dan informasi adalah Pusat Koperasi Kredit Jakarta (Puskopdit Jakarta) yang memiliki tipe Koperasi Simpan Pinjam. Salah satu aktivitas yang dilakukan oleh Puskopdit Jakarta adalah memberikan pelatihan, seminar, dan workshop mengenai pengelolaan keuangan bagi para anggotanya. Pelatihan, pada dasarnya memiliki peranan penting untuk dapat membuat keputusan yang lebih bijak dengan meingkatkan skill dan pengetahuan. Abdulwahab \& AlDhaafri (2019) menyatakan bahwa pelatihan memoderasi pengaruh pengetahuan dan pembuatan keputusan. Puspitasari (2017) menjelaskan bahwa pelatihan yang efektif memoderasi kebiasaan atau gaya hidup inidvidu dalam pembuatan keputusan. Sedangkan Dome, Kemboi \& Koge (2017) menjelaskan bahwa pelatihan memoderasi persepsi risiko terhadap pembuatan keputusan. Penelitian ini bertujuan menggali peranan Koperasi dalam pengambilan keputusan keuangan rumah tangga dan diharapkan dapat memberikan kontribusi pengembangan literasi terkait dengan keputusan keuangan dan peranan Koperasi dalam pengembailan keputusan keuangan.

\section{KAJIAN PUSTAKA \\ Behavioral Finance}

Tradisional finance mengasumsikan bahwa individua atau investor adalah rasional yang mengimplementasikan proses pengambilan keputusan efisien untuk memaksimalkan utilitasnya (Byrne \& Brooks, 2008). Byrne \& Brook (2008) juga menyatakan bahwa behavioral finance diformulasikan dengan berbagai alternatif bahwa investor tidak rasional dan cenderung untuk menunjukkan perilaku yang bias dalam pembuatan keputusan keuangan. Salah satu contoh dari behavioral bias adalah overconfidence atau terlalu percaya diri dan overoptimicm atau terlalu optimis. Investor cenderung terlalu memiliki proyeksi yang lebih atau ekspektasi yang tinggi atas investasinya. Behavioral finance bertujuan untuk menjelaskan perilaku investor dalam proses pembuatan keputusan yang juga melibatkan ketidakrasionalan, emosi, optimism, kerakusan, dan juga ketakutan (Stupavsky, 2018). Sedangkan Ricciardi \& Simon (2000) menjelaskan bahwa dasar dari behavioral finance adalah dari 3 bidang ilmu yang berbeda (finance, psikologi, dan sosiologi).

Behavioral finance didasarkan pada studi yang terkait dengan proses pengambilan keputusan pada penentuan nilai, fungsi keuangan, termasuk di dalamnya melibatkan aktivitas alokasi asset yang dimiliki. Psikologi, merupakan bidang ilmu yang mempelajari bagaimana faktor-faktor internal individu, seperti mental, faktor eksternal, dan berbagai keterkaitannya pada perilaku individu. Berbagai studi pada bidang psikologi bertujuan menjelaskan bias pada persepsi keuangan. Sedangkan sosiologi memandang bagaimana keterkaitan antara perilaku sosial individu dan perilaku kelompok. Hal tersebut juga terkait dengan hubungan sosial dan pengaruh hubungan sosial tersebut pada sikap, kepercayaan, dan perilaku individu. Integrasi dari berbagai bidang studi yang berbeda akan memberikan pemahaman yang lebih baik tentang behavioral finance dan studi mengenai finance secara umum. Tversky \& Kahneman (1971) menjelaskan bahwa kesalahan umum pada kepercayaan individua ada pada sampel statistic yang juga menjadi awal studi behavioral finance.

\section{Mental Accounting}

Mental accounting dapat didefinisikan sebagai sikap terkait dengan uang. Hal tersebut didasari dengan konsep bahwa individu pada dasarnya cenderung memiliki opini yang berbeda dalam menilai uang. Thaler (1999) mendefinisikan mental accounting sebagai operasi kognitif yang digunakan oleh rumah tangga dan individu untuk melakukan evaluasi, mengorganisasi, dan mengendalikan aktivitas keuangannya. Terdapat tiga komponen dari mental accounting (Thaler, 1999), yaitu: menangkap outcome dari persepsi dan pengalaman, proses pembuatan keputusan, evaluasinya. Secara umum, sistem akuntansi melibatkan berbagai analisa dari input menjadi output. Proses tersebut juga menjelaskan mengenai bagaimana proses keputuan keuangan individu terkait dengan berbagai pilihan, nilai, dan uang. Komponen lainnya adalah terkait dengan aktivita dari setiap akun. Input, meliputi sumber daya dan pendanaan yang digunakan. Misalnya, klasifikasi pengeluaran dan notifikasi untuk makanan, tagihan listrik, dan lain sebagainya. Sumber dana juga dapat diklasifikasikan sebagai pendapatan regular dan tidak reguler. Komponen lain dari mental accounting adalah terkait dengan frekeunsi akun, seperti harian, mingguan, bulanan, dan lain sebagainya. 
Mental accounting pada dasarnya juga terkait dengan aktivitas budgeting yang sangat penting sebagai komponen pembuatan keputusan individu. Menurut Santi, Sahara \& Kamaludin (2019), mental accounting merupakan konsep yang meliputi aspek psikologi dan mempengaruhi individu untuk kemudian mengkategorikan berbagai sumber pendanaan dan alokasi dari pendanaan tersebut untuk kemudian dibelanjakan atau dikonsumsi. Mental accounting pertama kali dikemukaan oleh Richard Thaler. Mental accounting juga melibatkan tingkat utilitas berbeda dari individu yang mempengaruhi keputusan keuangannya, termasuk di dalamnya menabung, berinvestasi, dan perilaku lainnya.

\section{Prospect Theory}

Prospect theory diperkenalkan oleh Daniel Kahneman dan Amos Tversky pada tahun 1979. Kahneman \& Tversky (1979) meneliti mengenai bagaimana individu mempersepsikan keuntungan dan kerugian pada kondisi yang tidak pasti dan berisiko. Kahneman \& Tversky (1979) menjelakan bahwa pengambilan keputusan dimulai dari framing, kemudian pertimbangan, proses evaluasi, dan pemilihan alternative. Teori ini pada dasarnya menjelaskan tentang bagaimana individu membuat keputusan dalam kondisi atau situasi yang berisiko dan berdasarkan pada judgement. Proses pengambilan keputusan dalam kondisi yang berisiko pada dasarnya merupakan proses yang kompleks dan membutuhkan banyak pertimbangan. Uzhga-Rebrov \& Grabusts (2021) menyatakan bahwa pengambilan keputusan dapat diklasifikasikan ke dalam tiga kelompok: Pengambilan keputusan dalam kepastian, di mana akan sangat terkait dengan pemilihan berbagai alternative; pengambilan keputusan pada kondisi berisiko yang melibatkan tidak hanya pilihan berbagai alternatif, akan tetapi aspek-aspek ketidakpastian, pengambilan keputusan pada kondisi ketidakpastian yang terkait dengan pemilihan alternative dan berbagai kejadian acak yang tidak terspesifikasi. Selain itu, ketersediaan informasi sangatlah penting dalam proses pengambilan keputusan khususnya pada kondisi yang berisiko. Informasi dan faktor lain yang relevan akan membantu individu dalam memilih berbagai alternatif dan membuat keputusan.

\section{Pengaruh Literasi Keuangan terhadap Keputusan Keuangan Keluarga}

Literasi keuangan mencerminkan pemahaman keuangan seorang inidvidu. Diharapkan dengan tingkat literasi keuangan yang tinggi, individu dapat membuat keputusan keuangan yang lebih bijak terutama dalam masa pandemic Covid-19. Penelitian yang dilakukan oleh Prasad \& Nataraj (2017) menyatakan bahwa literasi keuangan memiliki pengaruh terhadap keputusan keuangan. Lusardi (2013); Fong, Koh, Mitchel, \& Rohwedder (2021 juga menyatakan bahwa literasi keuangan memberikan pengaruh positif terhadap keputusan keuangan. Oleh karena itu,

\section{H1. Literasi keuangan berpengaruh terhadap keputusan keuangan keluarga}

\section{Pengaruh Gaya Hidup terhadap Keputusan Keuangan Keluarga}

Gaya hidup sering dikaitkan dengan kebiasaan dan mencerminkan bagaimana individu menjalani kehiudpannya. Individu yang terbiasa dengan produk mewah tentunya akan memberikan alokasi tertentu dalam pengeluarannya untuk produk yang mewah. Akan tetapi sebaliknya, jika individu memiliki kebiasaan melakukan pembelian sederhana, maka merek bukan merupakan satu-satunya pertimbangan dalam pembuatan keputusan pengeluaran. Penelitian yang dilakukan oleh Lin \& Shih (2012); Sahoo, Behera, \& Sahoo (2017) menemukan bahwa gaya hidup berpengaruh terhadap keputusan keuangan.

\section{H2. Gaya hidup berpengaruh terhadap keputusan keuangan keluarga}

\section{Pengaruh Persepsi Risiko terhadap Keputusan Keuangan Keluarga}

Individu pada dasarnya akan mempersepsikan risiko tertentu pada setiap produk/ layanan keuangan. Persepsi risiko mencerminkan cara pandang seseorang atau individu dalam melihat suatu ketidakpastian. Sitkin \& Weingart (1995) menyatakan bahwa individu memiliki preferensi dan memiliki perepsi berbeda atas produk/ layanan keuangan. Persepsi risiko yang tinggi biasanya akan identik dengan perasaan yang lebih aman atas produk yang berisiko, dan juga sebaliknya. Ainia \& Lutfi (2019), Bairagi \& Chakraborty (2018) menemukan bahwa persepsi risiko berpengaruh terhadap keputusan keuangan.

H3. Persepsi risiko berpengaruh terhadap keputusan keuangan keluarga 
Pelatihan dari Koperasi sebagai Variable Moderasi pada Keputusan Keuangan Keluarga Koperasi merupakan salah Lembaga keuangan non-bank yang memiliki tujuan untuk mensejahterakan para anggotanya. Salah satu prinsip Koperasi adalah pendidikan, pelatiham dan informasi. Melalui prinsip tersebut, diharapkan Koperasi memiliki peranan lebih untuk dapat mensejahterakan anggotanya melalui pelatihan, edukasi, seminar, workshop dan lain sebagainya. Abdulwahab \& Al-Dhaafri (2019) menyatakan bahwa pelatihan memoderasi pengaruh pengetahuan dan pembuatan keputusan. Puspitasari (2017) menjelaskan bahwa pelatihan yang efektif memoderasi kebiasaan atau gaya hidup inidvidu dalam pembuatan keputusan. Sedangkan Dome, Kemboi \& Koge (2017) menjelaskan bahwa pelatihan memoderasi persepsi risiko terhadap pembuatan keputusan.

H4. Pelatihan dari Koperasi memoderasi pengaruh literasi keuangan terhadap keputusan keuangan keluarga

H5. Pelatihan dari Koperasi memoderasi pengaruh gaya hidup terhadap keputusan keuangan keluarga

H6. Pelatihan dari Koperasi memoderasi pengaruh persepsi risiko terhadap keputusan keuangan keluarga

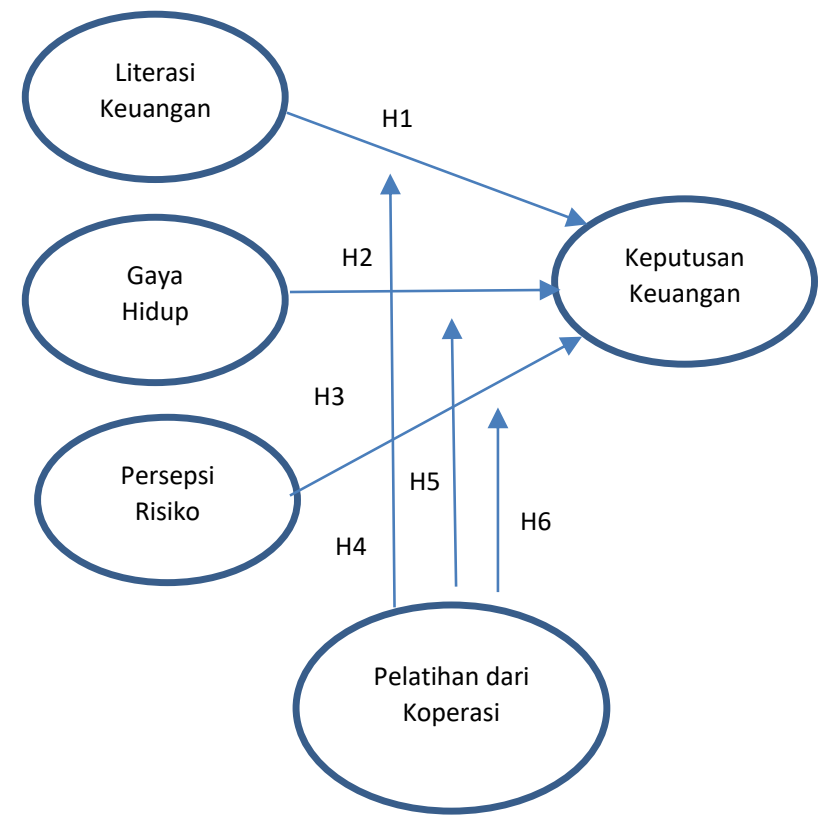

\section{Gambar 1. Kerangka Model Penelitian}

\section{METODE}

\section{Desain Penelitian}

Penelitian ini merupakan penelitian kuantitatif dengan menggunakan data berupa angka dengan model yang sistematis. Penelitian ini menggunakan data primer dan juga data sekunder. Data primer merupakan data yang diperoleh langung dari sumber data, misalnya melalui wawancara, observasi, survei, dan lain sebagainya. Data primer dalam penelitian ini diperoleh melalui kuisioner secara online maupun offline. Sedangkan data sekunder merupakan data yang diproses dan kemudian diperoleh oleh peneliti dari sumber lainnya, seperti buku, jurnal, laporan pemerintah atau institusi, atau juga sumber lain yang relevan. Data sekunder penelitian ini digunakan untuk memberikan penjelasan lebih detail dalam penelitian.

\section{Populasi dan Sampel}

Populasi dalam penelitian ini adalah semua anggota Pusat Koperasi Kredit Jakarta (Puskopdit Jakarta). Penelitian ini mengacu pada Hair \& et. al. (2010) dalam perhitungan sampel yang menjelaskan jumlah sampel minimal adalah 100. Kemudian, secara umum jumlah minimal sampel dapat dihitung dengan paling tidak 5 kali dari jumlah item kuisioner. Sampel, 
merupakan bagian yang sangat penting dalam penelitian, total sampel dalam penelitian ini adalah 185 sampel. Penelitian ini menggunakan metode purposive sampling sebagai Teknik pengambilan sampel dengan kriteria: merupakan anggota Puskopdit Jakarta dengan minimal lama keanggotaan 2 tahun, menikah, dengan usia 20-50 tahun. Penelitian ini dilakukan selama pandemi Covid-19 yang juga bertujuan meneliti bagaimana rumah tangga membuat keputusan keuangan pada saat pandemi Covid-19.

\section{Teknik Analisis}

Untuk melakukan analisa, tahapan pertama dalam penelitian ini melakukan uji validitas dan reliabilitas. Uji validitas bertujuan untuk mengukur tingkat ketepatan instrument. Uji validitas dilakukan dengan menggunakan uji Pearson Correlation. Uji reliabilitas dilakukan untuk menjelaskan ketepatan instrument penelitian. Reliabilitas pada dasarnya mengindikasikan tingkat konsistensi suatu instrument. Pada dasarnya, uji reliabilitas dilakukan dengan melihat koefisien reliabilitas yang berkisar antara 0 sampai dengan 1.00. Penelitian ini menggunakan Chronbachs' Alpha untuk mengukur reliabilitas instrument. Variabel penelitian harus memiliki nilai minimum 0.6 untuk nilai Chronbachs' Alphanya. Jika nilainya kurang dari 0.6 , maka tidak reliabel. Selain itu, penelitian ini juga melakukan uji asumsi klasik yang meliputi uji normalitas, multikolinearitas, dan uji heteroskedastisitas sebelum melakukan pengujian lebih lanjut.

\section{Moderated Regression Analysis (MRA)}

Moderated Regression Analysis (MRA) juga dikenal sebagai uji interaksi yang pada dasarnya merupakan suatu bentuk khusus dari regresi linear berganda yang terdiri dari interaksi antar variabelnya dalam persamaan regresi. Interaksi dapat didefinisikan sebagai perkalian antara variabelnya, yaitu antara variable independent dan variable moderasi. Tujuan dari MRA adalah untuk menganalisa kemampuan dari variabel moderasi apakah memperkuat atau memperlemah pengaruh variabel independent terhadap variabel dependen.

\section{HASIL DAN PEMBAHASAN}

Tabel 1 Karakteristik Responden

\begin{tabular}{|c|c|c|c|}
\hline Item & Keterangan & Jumlah & Persentase \\
\hline \multirow{3}{*}{ Usia } & $20-30$ tahun & 48 & $25.94 \%$ \\
\hline & $31-40$ tahun & 16 & $8.65 \%$ \\
\hline & $41-50$ tahun & 121 & $65.41 \%$ \\
\hline \multirow{2}{*}{ Jenis kelamin } & Perempuan & 105 & $56.76 \%$ \\
\hline & Laki-laki & 80 & $43.24 \%$ \\
\hline \multirow{5}{*}{$\begin{array}{l}\text { Tingkat } \\
\text { Pendidikan }\end{array}$} & SMA/MA/SMK/MAK & 89 & $48.11 \%$ \\
\hline & S1 & 64 & $34.59 \%$ \\
\hline & SMP/MTs & 8 & $4.32 \%$ \\
\hline & D3 & 16 & $8.65 \%$ \\
\hline & S2 & 8 & $4.32 \%$ \\
\hline \multirow{4}{*}{ Pekerjaan } & Pengusaha & 16 & $8.65 \%$ \\
\hline & Ibu rumah tangga & 49 & $26.49 \%$ \\
\hline & Karyawan di perusahaan swasta & 80 & $43.24 \%$ \\
\hline & Lainnya & 40 & $21.62 \%$ \\
\hline \multirow{3}{*}{$\begin{array}{l}\text { Pengeluaran/ } \\
\text { bulan }\end{array}$} & $<\operatorname{Rp} 5.000 .000,00$ & 129 & $69.73 \%$ \\
\hline & $\operatorname{Rp} 5.000 .001,00-\operatorname{Rp} 10.000 .000,00$ & 48 & $32.43 \%$ \\
\hline & $>\operatorname{Rp} 10.000 .001,00$ & 8 & $4.32 \%$ \\
\hline
\end{tabular}

Tabel 1 menunjukkan karakteristik responden penelitian ini yang terdiri dari usia, jenis kelamin, tingkat Pendidikan, pekerjaan, dan pengeluaran. Berdasarkan data, mayoritas 
responden berusia 41-50 yaitu sebesar 65.41\%, 20-30 tahun sebanyak 48 responden (25.92\%), dan 21-40 tahun sebanyak 16 responden (8.65\%). Mayoritas responden adalah perempuan dengan jumlah 105 responden yang mencerminkan $56.76 \%$ dari total responden, sedangkan laki-laki sebesar 80 responden atau sekita 43.24\%. Mayoritas responden memiliki tingkat Pendidikan SMA/ MA/ SMK/ MAK yang berjumlah 89 responden atau 48.11\%, kemudian 64 responden atau 34.59\% adalah lulusan S1. Tingkat Pendidikan D3 sebesar 16 responden (8.65\%), sedangkan responden dengan tingkat pendisikan S2 dan SMP sebanyak 8 responden $(4.32 \%)$.

Pekerjaan dan pengeluaran memiliki informasi penting mengenai gambaran pendapatan rumah tangga dan pengeluaran yang dilakukan. Berdasarkan data, mayoritas responden bekerja sebagai karyawan di perusahaan swasta yaitu sebanyak 80 responden atau sekitar $43.24 \%$. Kemudian ibu rumah tangga sebanyak 49 responden atau sekitar $26.49 \%$ dari total responden. Pengusaha sekitar $8.65 \%$ atau 16 responden, kemudian profesi lainnya sebanyak 40 responden atau $21.62 \%$. Mayoritas responden memiliki pengeluaran kurang dari Rp 5.000.000,- setiap bulannya (129 responden atau 69.73\%), kemudian responden dengan pengeluaran Rp 5.000.0001,- - Rp 10.000.000,- sebesar 48 responden atau $31.43 \%$ dan responden dengan pengeluaran lebih dari Rp 10.000.001,- sebanyak 8 responden atau 4.32\%.

Tabel 2 Uji Validitas

\begin{tabular}{|c|c|c|c|c|c|c|c|c|c|}
\hline \multicolumn{2}{|c|}{$\begin{array}{l}\text { Financial } \\
\text { Decision }\end{array}$} & \multicolumn{2}{|l|}{$\begin{array}{l}\text { Financial } \\
\text { Literacy }\end{array}$} & \multicolumn{2}{|l|}{ Lifestyle } & \multicolumn{2}{|c|}{ Perceived Risk } & \multicolumn{2}{|c|}{$\begin{array}{l}\text { Training } \\
\text { Cooperatives }\end{array}$} \\
\hline FIN1 & $.493^{* *}$ & LK1 & $.808^{* *}$ & GH1 & $.759^{* *}$ & PR1 & $.705^{* *}$ & TRAIN1 & $.872^{* *}$ \\
\hline FIN2 & $.729^{* *}$ & LK2 & $.880^{* *}$ & $\mathrm{GH} 2$ & $.679^{* *}$ & PR2 & $.855^{* *}$ & TRAIN2 & $.894^{* *}$ \\
\hline FIN3 & $.778^{* *}$ & LK3 & $.878^{* *}$ & GH3 & $.609^{* *}$ & PR3 & $.798^{* *}$ & TRAIN3 & $.895^{* *}$ \\
\hline FIN4 & $.787^{* *}$ & LK4 & $.893^{* *}$ & GH4 & $.532^{* *}$ & PR4 & $.557^{* *}$ & TRAIN4 & $.853^{* *}$ \\
\hline FIN5 & $.743^{* *}$ & LK5 & $.558^{* *}$ & GH5 & $.633^{* *}$ & PR5 & $.761^{* *}$ & TRAIN5 & $.932^{* *}$ \\
\hline \multirow[t]{4}{*}{ FIN6 } & $.257^{* *}$ & LK6 & $.650^{* *}$ & GH6 & $.865^{* *}$ & PR6 & $.843^{* *}$ & TRAIN6 & $.901^{* *}$ \\
\hline & & LK7 & $.735^{* *}$ & GH7 & $.775^{* *}$ & PR7 & $.605^{* *}$ & & \\
\hline & & LK8 & $.804^{* *}$ & GH8 & $.726^{* *}$ & & & & \\
\hline & & LK9 & $.835^{* *}$ & GH9 & $.642^{* *}$ & & & & \\
\hline
\end{tabular}

Tabel 2 menunjukkan hasil uji validitas. Penelitian ini menggunakan uji Pearson Correlation untuk menguji validitas. FIN merupakan keputusan keuangan, LK adalah literasi keuangan, GH adalah gaya hidup, PR adalah persepsi risiko, dan TRAIN adalah pelatihan yang dilakukan oleh Koperasi. Nilai $r$ table untuk 185 data sampel adalah 0.1443 dan semua hasil uji validitas memiliki nilai yang lebih besar dari 0.1443 sehingga semua instrument adalah valid.

Tabel 3 Uji Reliabilitas

\begin{tabular}{lll}
\hline Variable & $\begin{array}{l}\text { Cronbach's } \\
\text { Alpha }\end{array}$ & $\begin{array}{l}\text { N } \\
\text { items }\end{array}$ \\
\hline \hline Financial Decision & 0.732 & 6 \\
\hline Financial Literacy & 0.918 & 9 \\
\hline Lifestyle & 0.863 & 9 \\
\hline Perceived Risk & 0.858 & 7 \\
\hline Training by Cooperative & 0.946 & 6 \\
\hline
\end{tabular}

Tabel 3 menunjukkan hasil uji reliabilitas. Penelitian ini menggunakna Cronbach's Alpha untuk menguji validitas. Berdasarkan data, nilai Cronbach Alpha semua variabel di atas 0.6 sehingga semua instrumen reliabel. 
Tabel 4 Moderated Regression Analysis (MRA)

\begin{tabular}{llll}
\hline & Coefficient & t & Sig. \\
\hline \hline (Constant) & 6.911 & 1.127 & 0.261 \\
\hline LK & 0.918 & 2.681 & $0.008^{*}$ \\
\hline GH & 0.655 & 1.858 & 0.065 \\
\hline PR & 2.596 & 5.619 & $0.000^{*}$ \\
\hline TRAIN & 0.076 & 0.347 & 0.729 \\
\hline LK*TRAIN & 0.040 & 3.344 & $0.001^{*}$ \\
\hline GH*TRAIN & 0.033 & 2.676 & $0.008^{*}$ \\
\hline PR*TRAIN & 0.093 & 5.636 & $0.000^{*}$ \\
\hline
\end{tabular}

Tabel 4 menunjukkan hasil uji Moderated Regression Analysis (MRA). Berdasarkan data, variabel literasi keuangan berpengaruh terhadap keputusan keuangan rumah tangga karena memiliki tingkat signifikasi kurang dari 5\%. Gaya hidup tidak berpengaruh terhadap keputusan keuangan rumah tangga karena memiliki tingkat signifikansi lebih dari 5\%. Persepsi risiko memiliki tingkat signifikasi kurang dari 5\% sehingga persepsi risiko berpengaruh terhadap keputusan keuangan keluarga. Sedangkan interaksi antara variable independent dan moderasi berpengaruh terhadap keputusan keuangan keluarga dan variabel moderasi tidka berpengaruh terhadap keputusan keuangan keluarga. Sehingga variabel moderasi merupakan pure moderator.

Hasil penelitian menunjukkan bahwa literasi keuangan berpengaruh terhadap keputusan keuangan keluarga pada masa pandemic Covid-19. Hal tersebut sesuai dengan penelitian yang dilakukan oleh Prasad \& Nataraj (2017) dan Mitchell (2005) yang menemukan bahwa literasi keuangan berpengaruh terhadap keputusan keuangan. Hasil penelitian juga menunjukkan bahwa semakin tinggi tingkat literasi keuangan, maka akan membantu rumah tangga dalam membuat keputusan keuangan dengan lebih bijak. Literasi keuangan merupakan hal penting yang terkait dengan pengetahuan, keahlian, dan pengalaman terkait dengan keuangan, khususnya pada saat pandemi Covid-19. Pemahaman mengenai produkproduk dan layanan keuangan akan membantu rumah tangga untuk memilih produk yang paling sesuai untuk menabung, proteksi, maupun investasi. Hal tersebut juga akan membantu individu dalam mengantisipasi ketidakpastian di masa yang akan datang, termasuk pandemi Covid-19.

Gaya hidup tidak berpengaruh terhadap keputusan keuangan keluarga pada masa pandemi Covid-19. Hal tersebut tidak konsisten dengan penelitian yang dilakukan oleh Sahoo, Behera, \& Sahoo (2017) dan Nagpal \& Bodla (2009) yang menunjukkan bahwa gaya hidup berpengaruh terhadap keputusan keuangan individu. Gaya hidup pada dasarnya mencerminkan cara hidup seseorang, termasuk di dalamnya aktivitas, ketertarikan, dan opini. Gaya hidup tidak berpengaruh terhadap keputusan keuangan mencerminkan bahwa gaya hidup cenderung berubah dengan adanya berbagai faktor, termasuk teknologi. Misalnya, pada masa pandemi Covid-19, individu akan jarang keluar rumah, sehingga mereka lebih mengoptimalkan penggunaan teknologi yang lebih efektif dan efisien.

Persepsi risiko berpengaruh terhadap keputusan keuangan keluarga pada masa pandemi Covid-19. Hal tersebut sesuai dengan penelitian yang dilakukan oleh Ainia \& Lutfi (2019); Bairagi \& Chakraborty (2018) yang menunjukkan bahwa persepsi risiko berpengaruh terhadap keputusan keuangan. Setiap aktivitas keuangan pada dasarnya membutuhkan berbagai pertimbangan, termasuk di dalamnya melakukan evaluasi dari berbagai alternatif. Semakin individu mempersepsikan suatu produk aman, maka akan semakin mudah dalam membuat keputusan keuangan. Sebaliknya, jika individu tidak mempersepsikan suatu produk aman, maka individu tersebut akan membutuhkan waktu lebih lama dan memiliki kecenderuangan tidak mengeksekusi pemilihan produk tersebut.

Pelatihan yang dilakukan oleh Koperasi memoderasi pengaruh literasi keuangan, gaya hidup, dan persepsi risiko terhadap keputusan keuangan pada masa pandemi Covid-19. Hal tersebut menunjukkan bahwa pelatihan yang dilakukan oleh Koperasi dapat memperkuat 
atau memperlemah literasi keuangan, gaya hidup, dan persepsi risiko terhadap keputusan keuangan. Dalam penelitian ini, koefisien menunjukkan tanda positif sehingga dapat memperkuat semua pengaruh variabel independent terhadap dependen. Semakin efektif pelatihan yang dilakukan oleh Koperasi diharapkan dapat lebih membantu individu untuk membuat keputusan keuangan dengan tingkat literasi keuangan yang dimiliki oleh individu, gaya hidup, maupun persepsi risiko dari sebuah produk.

\section{KESIMPULAN}

\section{Kesimpulan}

Hasil penelitian ini menunjukkan bahwa literasi keuangan berpengaruh terhadap keputusan keuangan keluarga pada masa pandemi Covid-19. Gaya hidup tidak berpengaruh terhadap keputusan keuangan keluarga, dan persepsi risiko berpengaruh terhadap keputusan keuangan keluarga pada masa pandemi Covid-19. Selama masa pandemi, yang merupakan kondisi penuh dengan ketidakpastian akan membuat individu mengalami kesulitan dalam pembuatan keputusan. Sehingga diharapkan dengan literasi keuangan yang baik dan persepsi risiko yang aman dapat berpengaruh terhadap keputusan keuangan. Pelatihan dari Koperasi merupakan pure moderator untuk semua pengaruh variabel independent terhadap dependen. Menunjukkan bahwa pelatihan dari Koperasi sangatlah penting untuk menunjang keputusan keuangan yang bijak.

\section{Implikasi Praktis / Teoritis}

Hasil dari penelitian menunjukkan bahwa sangatlah penting bagi individu untuk meningkatkan tingkat literasi keuangannya sehingga dapat membuat keputusan keuangan dengan lebih bijak. Pemerintah dan Lembaga keuangan, khususnya Koperasi diharapkan dapat meningkatkan literasi keuangan masyarakat untuk menunjang keputuan keuangan yang lebih bijak. Keluarga perlu memiliki gaya hidup yang konsisten dan menyesuaikan dengan kondisi keuangan sehingga dapat menunjang keputusan keuangan yang bijak. Individu, dalam hal ini keluarga, perlu mengenali persepsi risikonya agar dapat lebih bijak dalam pembuatan keputusan. Peran Koperasi dengan prinsip pendidikannya diharapkan terus dilakukan dan dilakukan lebih terstruktur untuk menunjang para anggotanya dalam mencapai kesejahteraan.

\section{Keterbasan dan Saran}

Penelitian ini memiliki beberapa keterbatasan, antara lain hanya meneliti pengaruh langsung antara variabel independent terhadap variabel dependen. Penelitian selanjutnya dapat melakukan eksplorasi dengan menggunakan variabel intervening untuk memberikan gambaran yang lebih komprehensif dalam pengambilan keputusan keuangan.

\section{REFERENSI}

Abdulwahab, A. A., \& Al-Dhaafri, H. S. (2019). The Moderating Role Training on the Relationship Between Strategy Management, Information Technology Management and Organizational Performance of Sharjah Police. PEOPLE: International Journal of Social Sciences, Vol. 5, Issue 1, 866-886.

Ainia, N. S., \& Lutfi , L. (2019). The Influence of Risk Perception, Risk Tolerance, Overconfidence, and Loss Aversion Towards Investment Decision Making. Journal of Economics, Business, and Accountancy Ventura, Vol. 21, No. 3, 401-413.

Bairagi, P., \& Chakraborty, A. (2018). Influence of Risk Perception on Retail Investors' Decision Making. Asian Journal of Management. 9 (2).

Bei, L.-T. (2000). The Whitepaper on Lifestyle: A Report of the 2000 Survey on Taiwanese Consumption Habits. Taipei: Business Weekly Publications.

Bello, A. (2005). The Role of Cooperative Societies in Economic Development. MPRA Paper No. 23161.

Byrne, A., \& Brooks, M. (2008). Behavioral Finance: Theories and Evidence. The Research Foundation of CFA Institute 
Dewi, N. K. (2021, June 8). www.thejakartapost.com. Diambil kembali dari Maintaining Household Spending Recovery Momentum: https://www.thejakartapost.com/news/2021/06/08/maintaining-householdspending-recovery-momentum.html

Dome, R., Kemboi, A., \& Koge, M. (2017). Moderating Effect of Employee Training on the Relationship between Organizational Commitment and Employee Performance among Insurance Firms in Eldoret, Kenya. IOSR Journal Of Humanities And Social Science (IOSR-JHSS), Vol. 22, Issue 11, 53-39.

Fong, J. H., Koh, B. S., Mitchell, O., \& Rohwedder, S. (2021). Financial Literacy and Financial Decision-Making at Older Ages . Pacific-Basin Finance Journal 65, 1-17.

Hair \& et. al. (2010). Multivariate Data Analyisis Seventh Edition. Pearson Prentice Hall.

Halid, N. (2014). Koperasi Pilar Negara. Jakarta: Jetpress \& Dekopin.

Kahneman, D., \& Tversky, A. (1979). Prospect Theory: An Analysis of Decision under Risk. Econometrica, 47 (2), 263-291.

Kim, J., Gutter, M. S., \& Spangl, T. (2017). Review of Family Financial Decision Making: Suggestions for Future Research and Implications for Financial Education. Journal of Financial Counseling and Planning, Vol. 28, No. 2, 253-267.

Lin, L.-Y., \& Shih, H.-Y. (2012). The Relationship of University Student's Lifestyle, Money Attitude, Personal Value and their Purchase Decision. International Journal of Research in Management, Issue 2, Vol. 1.

Lusardi, A. (2013). Numeracy, Financial Literacy, and Financial Decision-Making. NBER Working Paper Series, Working Paper 17821, 1-14.

Muhyiddin, \& Nugroho, H. (2021). A Year of Covid-19: A Long Road to Recovery and Acceleration of Indonesia's Development. Jurnal Perencanaan Pembangunan, Vol. V, No. 1, 1-19.

Nagpal, S., \& Bodla, B. (2009). Impact of Investors' Lifestyle on Their Investment Pattern: An Empirical Study. The IUP Journal of Behavioral Finance, VI (2), 29-51.

OJK. (2020, December 1). Survei Nasional Literasi dan Inklusi Keuangan 2019. Diambil kembali dari www.ojk.go.id: https://www.ojk.go.id/id/berita-dankegiatan/publikasi/Pages/Survei-Nasional-Literasi-dan-Inklusi-Keuangan2019.aspx

Parnell, E. (2001). The Role of Cooperatives and other Self-Help Organizations in Crisis Resolution and Socio-Economic Recovery. International Labour Organization.

Prasad, S., \& Nataraj. (2017). Impact of Financial Literacy on Financial Decision Making - A Study with Reference to Retail Investors in Chennai . International Journal of Marketing, Financial Services \& Management Research, Vol. 6, No. 2, 71-81.

Puspitasari, N. W. (2017). Keterlibatan dan Kemampuan Teknik Personal pada Kinerja SIA dengan Pendidikan dan Pelatihan sebagai Variabel Moderasi. E-Journal Akuntansi Universitas Udayana, Vol. 20, No. 1.

Ricciardi, V., \& Simon, H. (2000). What is Behavioral Finance? Business, Education \& Technology Journal, 2, 1-9.

Sahoo, S. K., Behera, Y. D., \& Sahoo, T. R. (2017). Secured Life Style behind the Investment Decision is the True Mirror of The Indian Financial Market: An Empirical Justification. International Journal of Science, Engineering and Management (IJSEM), Vol 2, Issue 12, 129-132.

Santi, F., Sahara, N. V., \& Kamaludin. (2019). The Effect of Mental Accounting on Student's Investment Decisions: A Study at Investment Gallery (GI) FEB University of Bengkulu and Syariah Investment Gallery (GIS) FEB IAIN Bengkulu. Jurnal Ilmiah Ekonomi Bisnis, Vol. 24, No. 2.

Sindhu, K., \& Kumar, S. (2014). Influence of Risk Perception of Investors on Investment Decisions: An Empirical Enalysis. Journal of Finance and Bank Management, 2 (2), 1525.

Sitkin, S., \& Weingart, L. (1995). Determinants of Risky Decision-Making Behavior: A Test of the Mediating Role of Risk Perceptions and Propensity. Academy of Management Journal, 38 (6), 1573-1592.

Stupavský, M. (2018). Behavioral Finance Foundations for Investors. CFA Institute. 
tempo.co. (2021). Indonesia's Economy Down 2.19\% in Q4/2020 . Diambil kembali 21 Maret 2021 dari https://en.tempo.co: https://en.tempo.co/read/1430105/indonesiaseconomy-down-2-19-in-q42020

Thaler, R. H. (1999). Mental Accounting Matters. Journal of Behavioral Decision Making, 12, 183-206.

Tversky, A., \& Kahneman, D. (1971). Belief in the Law of Small Numbers. Psychological Bulletin, $76(2), 105-110$.

Uzhga-Rebrov, O., \& Grabusts, P. (2021). Cumulative Prospect Theory Version with Fuzzy Values of Outcome Estimates. Risk 9: 72.

\section{Profil Penulis

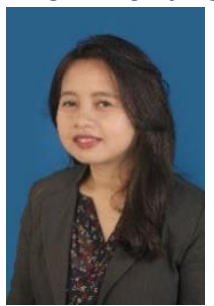

Diyan Lestari adalah dosen Prodi Manajemen Fakultas Bisnis dan Komunikasi, Institut Teknologi dan Bisnis Kalbis dengan pengalaman mengajar pada Manajemen Keuangan, Manajemen Keuangan Pribadi, dan Manajemen Keuangan Internasional. Memiliki ketertarikan pada penelitian terkait dengan corporate finance, perbankan, dan personal finance. Korespondensi dapat dilakukan melalui email: diyan.lestari@kalbis.ac.id.

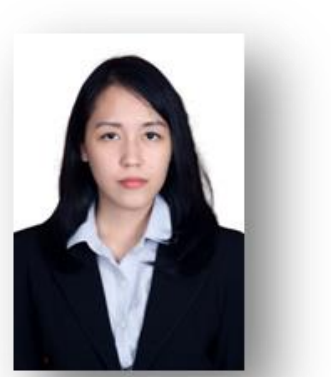

Vina Meliana adalah dosen Prodi Manajemen Fakultas Bisnis dan Komunikasi dengan pengalaman mengajar pemasaran seperti Manajemen Pemasaran, Pengembangan Produk dan Merek, dan Manajemen Citra. Penulis memiliki ketertarikan pada penelitian terkait dengan perilaku konsumen, merek, dan ekuitas merek. 